\title{
Surrealism and Photography Introduction
}

\author{
Wendy Grossman \\ Independent Scholar
}

In keeping with the first two issues of the Journal of Surrealism and the Americas, this third issue aims to broaden the horizon of critical concerns to which the publication is dedicated, turning our attention here to photographic contributions to the discourse of Surrealism and the Americas. Photography, of course, played a central role in surrealist practices since the movement's inception, as the plethora of scholarship on the topic has underscored. It is thus not surprising that as the movement gained adherents across the Atlantic, the medium would find its calling in this new context as well. The disparate nature of these practices, as evident in the essays that follow, illustrate the pluralistic manner in which surrealist ideas were incorporated into various photographers' work over the course of the twentieth century. Introducing photographic, art historical, and literary perspectives on the work of various photographers, the authors of these essays open an interdisciplinary dialogue, inviting further exploration of the issues they raise.

Perhaps most surprising among the candidates for examination within the concerns of this journal is Timothy O'Sullivan (1840-1882), whose nineteenthcentury photographs of the Western American frontier Ansel Adams characterized as "surrealistic and disturbing." This unusual and anachronistic portrayal of O'Sullivan's images of the pristine American landscape and its ultimate erasure from photographic discourse of the 1930s provide the provocative foundation for Britt Salvesen's opening essay. Investigating the intellectual and aesthetic investments at stake in debates over the nature of modernist photography, she provides new insight into how this discussion was circumscribed by the terms set in place by the newly established Museum of Modern Art and its principal photographic advocate, Beaumont Newhall. Salvesen's trajectory of the reception of O'Sullivan's photographs lays bare the ideological constructs through which photographs

Wendy Grossman: wagross@umd.edu

Copyright (C) 2008 (Wendy Grossman). Creative Commons Attribution-Noncommercial-No Derivative Works 3.0 Unported License. Available at http://jsa.asu.edu/ 
acquired meaning in this period, and the manner in which surrealist practices were marginalized in modernist histories of photography at a critical moment in the construction of these same narratives.

Salvesen's enlightening essay sets the stage in raising thought-provoking questions about reception and canon formation that one might also consider in relation to the other essays in this issue. What impact, for instance, did the ultimate abandonment of Adams' surrealist paradigm have on the reception of photographers discussed in two of these essays, Frederick Sommer (1905-1999) and Clarence John Laughlin (1905-1985)? Neither of them appeared in MoMA's seminal 1937 exhibition, "History of Photography," and they were consequently absent from Newhall's related publication, which still serves as a text for the field. ${ }^{1}$ Although, as Ian Walker notes, Sommer ultimately made a belated appearance in the 1982 revised edition of Newhall's publication, neither Laughlin nor Francesca Woodman (1958-1981) — the subjects of Lewis Kachur's and Katharine Conley's essays in this volume-have been recognized in any of the five editions.

Also of note is the fact that Laughlin and Woodman fare no better in Mary Warner Marien's Photography, A Cultural History, one of the more popular history of photography texts recently issued in revised edition in $2006 .^{2}$ Nor, for that matter, are either photographers mentioned in extensive studies on photography and surrealism, such as the catalogue for the landmark exhibition on this topic, L'amour fou. ${ }^{3}$ How then, we might ask, have the ideological tenets at play in Surrealism's marginalization in early photographic history that Salveson elucidates shaped subsequent narratives? How have restrictive definitions of what constitutes surrealist photography further influenced our understanding —or lack thereof —of these photographers? It is arguably not incidental, for instance, that the work under consideration here all features non-urban locales, outside the space of the cityscape that is conventionally associated with surrealist photography of the non-manipulated variety. ${ }^{4}$

Frederick Sommer's Arizona Landscapes come under examination in Walker's essay, which offers rare insight into the ideas and processes guiding this body of work and challenges us to rethink and broaden our very notions of what constitutes a surrealist photograph. Although photographs from this series have been reproduced frequently, this study contributes to a greater understanding of these images through intense scrutiny, broad contextualization, and lucid explication. Walker's keen observations and the facility with which he unveils the intricacies of Sommer's approach to his medium are clearly informed by his own experience as a photographer, and by his efforts to replicate-through his and Sommer's 
own camera - the composition, flatness, complexity, density of detail, and texture of Arizona Landscapes. Noting how the sharp focus and hyper-realism of these photographs - thanks to the large format view camera he was advised by Edward Weston to use - create an uncanny sense of the merging of the real and the dream, the author argues that Sommer drew upon his own discovery of convulsive beauty in the desert's details. He also addresses the process through which the Arizona Landscapes entered the discourse of Surrealism in reproduction in 1944 in the magazine $V V V$. Drawing attention to the manner in which these images were first incorporated into the surrealist narrative, Walker raises critical questions relating to the dissemination and reception of surrealist ideas in the United States in this period.

The notion of a "Surrealism of place" is a central concern of Kachur's essay, in which Clarence John Laughlin's photographs of the architecture of New Orleans, the graveyards and plantations around Louisiana, and the topography of Arizona provide the framework for a discussion of what the author defines as "Regional Surrealism." Reading Lauglin's photographs of New Orleans through the screen of Giorgio de Chirico's painting, Kachur gives new significance to role of Julian Levy and his New York gallery in the promotion of the photographer's work within the context of Levy's support for the figurative wing of Surrealism. Noting strong parallels between Laughlin's early photographs and the paintings of Giorgio de Chirico, as well as between his later photographs and the work of Salvador Dalí, the author argues for an understanding of this stylistic shift as an effort on the part of the photographer to engage in contemporary surrealist discourse on an international, rather than regional, level. Key to this transformation, Kachur argues, is Laughlin's actualization of "Dalís ambition to make the hallucinatory as precise as a sharp photograph." In linking Laughlin's photographs to specific visual traditions in surrealist painting, this essay opens this work to new interpretations; Kachur also illustrates how Laughlin's images both capitalized on and contributed to the reception of surrealist ideas in the 1940s.

Conley's investigation of the phantasmal photographs of Francesca Woodman departs from the other essays in several respects. Woodman is not only the sole female photographer explored in this issue but, as she was born in 1958, also belongs to a younger generation of artists. In a highly nuanced reading of Woodman's photographs as a reformulation of surrealist activity--specifically of Breton's definition of automatic writing--Conley effectively engages with the unique contextual and theoretical concerns her work raises. Situating these images in the liminal spaces between waking and dreaming, the author links the narrative qualities of Woodman's photographs to key surrealist concepts. 
But perhaps the most significant distinction between Woodman and the photographers discussed in the preceding texts is the idea of place expressed in the work itself. While landscape or architectural structures provided stimuli for Sommer and Laughlin--and indeed for O'Sullivan and Adams--Woodman concentrates on the body as the locus of automatic experience. This practice, as the author notes, is very much in the tradition of women surrealist artists before her. Informed by her expertise as a scholar of literary Surrealism, Conley provides an evocative interpretation of Woodman's images as "maps to inner space" that link the physical body with its "psychic interior." This intricate visual and textual reading contributes new insight into the artist and her work, expanding our understanding of the manner in which surrealist ideas infiltrated artistic activities well beyond their times.

Together these essays argue for a broadening of our definition of what constitutes a surrealist photograph, inviting further investigation into a rich and largely un-mined field of inquiry in which the intersecting interests of photography and Surrealism are to be found outside conventional European frameworks. While the four essays in this issue focus on photographers who worked principally in the United States, we hope that they will serve as a prelude and springboard to future examinations of surrealist photographic activities that have reached across the Americas.

1 Beaumont Newhall, The History of Photography from 1839 to the present, revised and enlarged edition (New York: Museum of Modern Art, 1982). Sommer is referenced in the text on pages 283 and 288, with his photograph of Max Ernst reproduced on page 286.

2 Mary Warner Marien, Photography, A Cultural History (Upper Saddle River, NJ:

Prentice Hall, 2006).

3 Rosalind Krauss and Jane Livingston, eds., L'Amour fou, exh. cat. (Washington: Corcoran Gallery / New York: Abbeville, 1985).

4 See, for example, Ian Walker, City Gorged with Dreams: Surrealism and Documentary

Photography in Interwar Paris (Manchester University Press, 2002). 